\title{
System of planning and evaluation of school meals
}

\author{
Ada Rocha*, Cláudia Afonso, M Cristina Santos, Cecília Morais, Bela Franchini and \\ Rui Chilro \\ Faculdade de Ciências da Nutrição e Alimentação, Universidade do Porto, Rua Dr. Roberto Frias, \\ 4200-465 Porto, Portugal
}

Submitted 2 October 2012: Final revision received 21 March 2013: Accepted 12 June 2013: First published online 7 August 2013

\begin{abstract}
Objective: To develop a software to plan and evaluate school meals according to the main national and international standards for foods and nutrition.

Design: Development of software.

Setting: Public schools, Portugal.

Subjects: School meals for students.

Results: The System of Planning and Evaluation of School Meals (SPARE) is a software that allows the planning of school meals in an effective and organized way, according to the main national and international standards for food and nutrition. The regular use of this tool enables the evaluation, monitoring and verification towards continuous improvement of the quality of school meals. Conclusions: The SPARE software aims to promote healthy eating by focusing on the planning and production of safe and adequate meals in the school environment. This software can be adapted to different age groups and to different contexts, attending to specific nutritional and food standards.
\end{abstract}

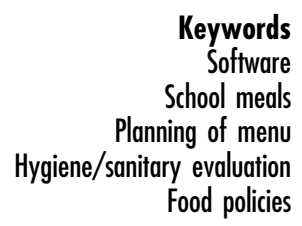

All food services responsible for the planning and provision of school meals should ensure food safety, nutritional balance and variety, not to mention social context, cultural and environmental adequacy. On this basis, the school - including teachers, staff, students and families - must be a place for promotion and reinforcement of healthy food habits by the dissemination of educational messages consistent with food and nutritional recommendations. Food availability at school must also contribute to the modulation of food behaviours and to the development of healthy eating habits.

The importance of promoting healthy eating habits has been reinforced by the findings of several epidemiological studies, which have shown the increasing prevalence of obesity in all age groups and emphasize the role of lifestyle factors in its development ${ }^{(1,2)}$. Portugal is considered one of the European countries with higher prevalence of overweight and obesity in childhood ${ }^{(3)}$. Recently, Pedrosa et ll $^{(4)}$ found the prevalence of overweight and obesity in children aged $7-9$ years to be $33 \%$ according to the classification of the International Obesity Taskforce ${ }^{(5)}$ and $28 \%$ according to the US Centers for Disease Control and Prevention standards ${ }^{(6)}$. In this context, the official Portuguese organization DirecçãoGeral da Saúde (Directorate-General of Health, Ministry of Health), through the Plataforma Contra a Obesidade (Platform Against Obesity), has been developing strategies to prevent and reduce the risk of obesity and overweight in childhood ${ }^{(7,8)}$.
Programmes that focus primarily on the younger population are crucial to establish and maintain healthy behaviours through life, by involving several social actors such as schools (through the intervention in school programmes, canteens, buffets and vending machines), municipalities, health authorities, family and others. In Portugal, the number of children and young people attending public schools is increasing every year ${ }^{(9)}$. The school is considered a privileged environment for health education, as it represents one of the major contexts for learning where habits and lifestyles are acquired and become solid ${ }^{(10,11)}$. The school canteen plays an important role and has gained an increasing responsibility concerning the food and nutrient intakes of children and young people. In reference to school meals' composition, besides nutritional balance, meals need to be planned and elaborated safely and to consider the social context, the environment and the protection and promotion of regional gastronomy, as well as sensorial aspects ${ }^{(12)}$.

To ensure respect for children's rights and well-being, it is critical to ensure the sustainable development of countries. Public health professionals have a responsibility to work in order to allow children and young people to have access to schools with high quality, not only in the pedagogical point of view but also with regard to food, with the aim to reduce health risks ${ }^{(13)}$.

School menus should be developed based on principles of healthy eating and also certifying food quality and safety ${ }^{(14)}$. A well-planned menu, with the regular supervision 
of technical staff, may be used simultaneously for the planning and production of meals and as a valuable tool for nutritional education. Furthermore, in terms of quality and safety, it is important to understand the conditions of the places where meals are produced and served. It is essential to perform a regular and objective, qualitative and quantitative evaluation of the structural and physical conditions of school food units, to ensure the application of good food handling and production practices towards a continuous improvement ${ }^{(15)}$.

Attempting to allow a more sustained action of schools, the software entitled System of Planning and Evaluation of School Meals (SPARE) was developed. SPARE is a project developed by the Faculdade de Ciências da Nutrição e Alimentação of the Universidade do Porto for the government initiative Plataforma Contra a Obesidade of the Direcção-Geral da Saúde, and fits the definition of strategies to promote healthy and balanced meals in the school environment of the Direcção-Geral de Inovação e Desenvolvimento Curricular (Directorate-General for Innovation and Curriculum Development, Ministry of Education and Science).

The main purpose of this software is to allow the planning and monitoring of school meals in a quick and organized system, according to national and international nutritional recommendations for children and young people. The aim of the present paper is to present SPARE - Portuguese software to be applied at schools for planning and evaluating menus.

\section{Software description}

The software includes four functionalities (Fig. 1).

\section{A. Planning of menus}

The development of the menu plan is based on the construction of technical sheets that include ingredients per capita for each component of the meal, as well as information concerning preparation procedures and cooking methods. This step is essential to allow further evaluation of nutritional adequacy for each age group, ranging from 3 to 18 years old.

Moreover, the software allows analysis of the variety of the menus by checking the information of the weekly and monthly menus as they are being created. It is possible to edit data from technical sheets and menus for potential adjustment. For the nutritional evaluation a database with Portuguese and non-Portuguese foods was created, based on the Portuguese Food Composition Database and other international databases, including British, Brazilian and Canadian ones ${ }^{(16-19)}$.

\section{B. Menu evaluation}

This item allows two distinct functionalities, namely the quantitative and the qualitative evaluation of menus. The quantitative evaluation considers the nutritional balance based on recommendations from the Direcção-Geral da Saúde and international organizations for the adequacy of energy and the contribution to energy values of different nutrients according to different age groups. For this purpose, and considering the Portuguese educational system, four age groups were created from kindergarten to the third cycle of studies in secondary schools. The evaluation item allows the validation of the menus that are considered nutritionally adequate, after completing all steps necessary to create the evaluation report. The qualitative evaluation

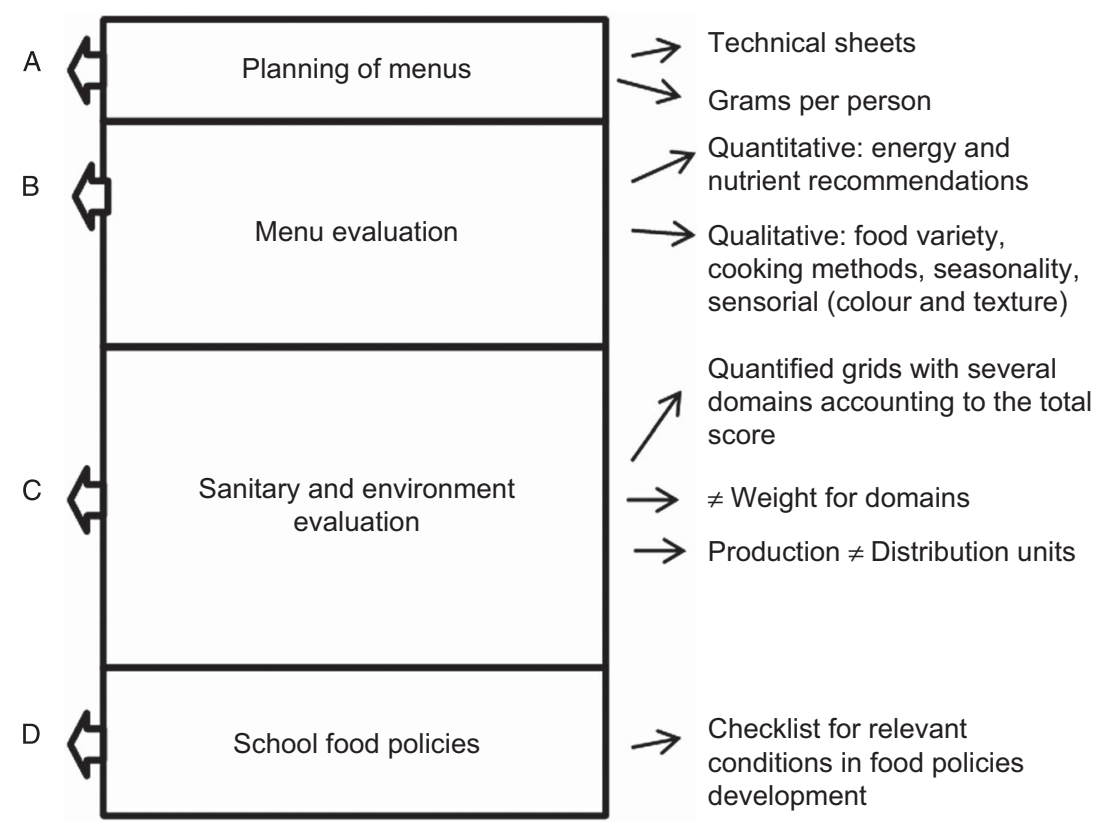

Fig. 1 Functionalities of the software (System of Planning and Evaluation of School Meals, SPARE) 
considers different aspects such as food variety, cooking methods, seasonality and sensory aspects of the meal, such as colour and texture.

\section{Sanitary and environment evaluation}

Quantified grids were developed to allow the evaluation and classification of food units/canteens regarding sanitary and environment items. The grids have their scientific base on the work of Portuguese researchers and according to Portuguese legislation, as well as international guidelines $^{(14,15)}$.

Two possibilities were considered: cooking units and distribution units. For each one, a different evaluation grid is available, which may be completed even if the other functions of the software are not used (used as independent items). Several domains are evaluated by the grid, namely structure, materials and equipment, environment and sanitary conditions, and the software produces an automatic report showing the non-conformities. This allows the establishment of recommendations for a continuous improvement focusing on the major requirements of each place.

The result of the evaluation itself consists of the diagnosis and monitoring of the unit and suggests intervention priorities.

\section{School food policies}

A checklist was created for diagnosis of the school situation concerning the promotion of healthy school meals. According to the results, it is possible to identify the need for more specific food policies for each school.

\section{Software development}

\section{Menu planning}

Menus are based on the use of high-quality foods and the adoption of healthy cooking techniques, considering as well the quantity of food served individually (portion). It is also recommended to use local/regional foods according to their seasonality ${ }^{(20)}$.

The whole meal must include a vegetable soup with a base of potato or beans and vegetables; a main dish including a protein source of vegetable or animal origin with a source of carbohydrates and vegetables (raw or cooked), adequate to the menu; and a dessert. Bread and water must also be provided. If there is a 'diet' option, this may contain a different source of protein if justified, for example by medical, religious or cultural reasons. The dessert must consist mainly of fruit in season and occasionally it can be replaced by a sweet dessert.

The menus for the month will enumerate the list of constituents, namely soup, regular main dish or 'diet' option (specifying the type of meat or fish) and dessert. It must also include information about nutritional composition (macronutrients and energy value) of the meals per capita.
Menu elaboration must include the technical sheets of all constituents, namely the food items used, portions, nutritional composition and cooking methods.

The operational procedure begins by accessing the software in the website (http://www.plataformacontraaobesidade.dgs.pt:8080/SPARE/index.html). It starts by choosing the first functionality 'Planning of meals'. The process starts by the choice of the main meal component that includes (1) soup, (2) source of protein (one of the following: $(2 \cdot 1)$ fish, $(2 \cdot 2)$ meat, $(2 \cdot 3)$ eggs), (3) source of carbohydrates, (4) vegetables and (5) dessert. After this step, the cooking method of the main meal component can be selected from raw, boiled, grilled, roast, stew, sautéed and fried. Afterwards it is possible to edit a specific component, adding all the ingredients used considering the cooking procedure. Its nutritional value will depend of the quantity of the ingredients and the cooking method used. For example, for the component 'grilled salmon', the main meal component 'fish' and the cooking method 'grilled' are chosen. Then, there is an option to select 'grilled salmon' from the food composition database and other ingredients can be added such as oil/fat. Another option includes the possibility to choose 'raw salmon' and add specific ingredients which can be different according to food services. The quantity of each ingredient should be included. All quantities are correspondent to total weight of foods and the software automatically transforms it into edible weight. This system offers the opportunity to choose any kind of ingredients, different from the usual/traditional recipe and cooking method, obtaining a technical sheet closer to the reality and more precise in terms of nutritional value for that food service.

In order to elaborate the technical sheets, for each of the components previously inserted, the name and the description of the preparation and cooking procedures will be added. Following the previous example of 'grilled salmon', at this time it is possible to describe the preparation procedures of the fish and how it is to be grilled. At any time the technical sheets may be checked and edited.

At this point and assuming that the database has enough technical sheets, the next step is to elaborate the menus. The plan can be scheduled from one menu (weekly menu) to four weeks of menus (monthly menu). The elaboration starts by the selection of a meal component (from our database) to each of the five main meal components, for each day of the week. At any time it is possible to see the variety of the menu represented by every component in a summary table. It displays, for example, how many times grilled salmon occurs during the period of analyses.

The software automatically produces two menu layouts (weekly and monthly) that may be displayed to the school community and archived in the school records as requested in the good practices procedures. 


\section{Specification of the meal components}

The vegetable soup must be prepared preferably using fresh potatoes and include at least four varieties of vegetables, include pulses two or three times per week, and olive oil should be used as the preferred fat for cooking. The soup portion served should be about $200 \mathrm{ml}$

The proportion of fish for the main dish during the week must be equal to or higher than that from meat and, according to international recommendations, the consumption of 'white meat' (chicken, turkey, rabbit) should be preferred to others. All visible fat and skin should be removed from the pieces. Fatty fish (salmon, sardine, tuna, mackerel), a good source of $n-3$ fatty acids, must be included once per week; the meals including eggs or egg products should be used once per week ${ }^{(21-24)}$.

It is recommended to use of a variety of vegetables and sources of carbohydrates. Raw or cooked vegetables should also be presented alternately. All raw vegetables should be previously sanitized.

The cooking methods should be varied, including boiling, grilling and stewing, following healthy culinary recommendations that include the addition of monounsaturated fat and avoid overheating of polyunsaturated fats. The frying method and stews with more fat should be used occasionally (only once per week), since they contribute to a high content in trans-fatty acids; products such as sweets and salty pastries, patties, pies, chocolate, sauces, mayonnaise, etc. should also be avoided. In the cooking preparations that require the use of milk and milk products, low fat content should be preferred ${ }^{(21-25)}$.

Added salt should be used in small quantities. It is recommended to improve the natural taste of foods by the use aromatic herbs and marinades with lemon juice, garlic, onion and spices. The use of industrialized foods and pre-cooked preparations should be avoided. In order to maximize taste, preserve nutritional quality and reduce fat and salt, the use of pressure cookers and vapour pots is recommended ${ }^{(20,22,23)}$.

The bread should be made from different cereals, with poorly refined flours, and should be varied during the week. Regarding dessert it should consist of fresh and varied fruit, in season. Fruit salad must not have added sugar, and must include several varieties of fruits and always a citrus one $\mathrm{e}^{(20,22,23)}$. Canned fruit must be considered a sweet dessert. Desserts with added sugar should be offered only once per week, preferably with milkbased ingredients, fruits or vegetables and eventually with nuts and dried fruit (e.g. apple cake, carrot cake, nut cake and Portuguese traditional desserts such as leite creme, aletria and arrozdoce). The recipes should be low in sugar and have a low fat content ${ }^{(7)}$. The beverages included in the school meals must be tap water and if necessary bottled water. The plating should be done in an appealing way, avoiding food preparation with the same textures and colours.

\section{Quantitative evaluation}

For the qualitative evaluation of the menus, it was considered that the total energy requirements for the day should be distributed in six meals: breakfast $20 \%$, mid-morning snack $10 \%$, lunch 30-35\%, afternoon snack $10 \%$, dinner $20-25 \%$ and late snack $5 \%(11,20)$

The total energy requirements for the different age groups (according to the Portuguese educational system) were calculated following the recommendations stated by the US Department of Agriculture in 2005 (Table 1) ${ }^{(26,27)}$.

For the distribution of total energy by macronutrients we followed the WHO recommendations from $2003^{(28)}$, establishing as lower and upper limits: 55 to $75 \%$ carbohydrate, 15 to $30 \%$ fat and 10 to $15 \%$ protein (Table 2). Only energy and macronutrients were considered in this approach.

\section{Qualitative evaluation}

The qualitative grid of menus evaluation is organized in six domains, each of them including several parameters with a total of forty items. The domains include: (i) general items; (ii) soup; (iii) meat, fish and eggs; (iv) cereals, cereal products and tubers; (v) vegetables and pulses; and (vi) dessert (Table 3).

The parameters were quantified according to their relative importance; for each domain a specific weight (value) was defined, in percentage, to obtain a general score ranging from 0 to $100 \%$. The obtained value can have a qualitative classification from 'not acceptable' to 'very good' (Table 4).

\section{Environment and sanitary evaluation}

As described above, two grids were elaborated to allow the collection of data in food units: for its characterization and for the diagnosis of both sanitary and functional facilities. These grids are quantified and may be used as monitoring tools; one for the cooking units and another for the distribution units. Filling in the grids allows to one combine information about structures and equipment, technical and human resources, and food handlers' self-control, considering as well the social and environment sustainability ${ }^{(14)}$.

The sanitary evaluation grid for cooking units includes twelve evaluation domains, each one including several parameters and accounting 145 items in total (Table 5). The sanitary evaluation grid for distribution units includes

Table 1 Daily energy requirements, by age group

\begin{tabular}{lccccc}
\hline & \multicolumn{2}{c}{ Total energy } & & \multicolumn{2}{c}{ Energy from lunch } \\
\cline { 2 - 3 } \cline { 6 - 6 } Age (years) & $\mathrm{kJ}$ & $\mathrm{kcal}$ & & $\mathrm{kJ}$ & $\mathrm{kcal}$ \\
\hline $1-3$ & 4812 & 1150 & & 1443 & 345 \\
$3-6$ & 5858 & 1400 & & 1757 & 420 \\
$6-10$ & 6862 & 1640 & & 2059 & 492 \\
$10-15$ & 8661 & 2070 & & 2598 & 621 \\
$15-18$ & 9958 & 2380 & & 2987 & 714 \\
\hline
\end{tabular}


Table 2 Recommendations for macronutrient distributions (for the meal and the whole day), by age group

\begin{tabular}{lrrrrc}
\hline & \multicolumn{4}{c}{ Age (years) } \\
\cline { 2 - 6 } & \multicolumn{1}{c}{$1-3$} & \multicolumn{1}{c}{$3-6$} & $6-10$ & $10-15$ & $15-18$ \\
\hline Carbohydrate $(\mathrm{g})$ & $47 \cdot 4-64 \cdot 7$ & $57 \cdot 8-78 \cdot 8$ & $67 \cdot 7-92 \cdot 3$ & $85 \cdot 4-116 \cdot 4$ & $98 \cdot 2-133 \cdot 9$ \\
Fat (g) & $5 \cdot 8-11 \cdot 5$ & $7 \cdot 0-14 \cdot 0$ & $8 \cdot 2-16 \cdot 4$ & $10 \cdot 4-20 \cdot 7$ & $11 \cdot 9-23 \cdot 8$ \\
Protein (g) & $8 \cdot 6-12 \cdot 9$ & $10 \cdot 5-15 \cdot 8$ & $12 \cdot 3-18 \cdot 5$ & $15 \cdot 5-23 \cdot 3$ & $17 \cdot 9-26 \cdot 8$ \\
\hline
\end{tabular}

Table 3 Domains for qualitative menu evaluation and their respective values

\begin{tabular}{lc}
\hline Domain & Value $(\%)$ \\
\hline 1. General items & 50 \\
2. Soup & 10 \\
3. Meat, fish and eggs & 10 \\
4. Cereals, cereal products and tubers & 10 \\
5. Vegetables and pulses & 10 \\
6. Dessert & 10 \\
Total & 100 \\
\hline
\end{tabular}

Table 4 Qualitative classification of results

\begin{tabular}{lc}
\hline Classification & Value (\%) \\
\hline Very good & $90-100$ \\
Good & $75-90$ \\
Acceptable & $50-75$ \\
Not acceptable & $<50$ \\
\hline
\end{tabular}

Table 5 Description of the twelve domains for sanitary evaluation of cooking units and their respective values

\begin{tabular}{|c|c|c|}
\hline Domain & & Value (\%) \\
\hline 1. & $\begin{array}{l}\text { Functional and technical conditions of rest } \\
\text { rooms for workers and costumers }\end{array}$ & $6 \cdot 0$ \\
\hline 2. & $\begin{array}{l}\text { Functional and technical conditions of } \\
\text { reception zone and food items } \\
\text { characteristics }\end{array}$ & $7 \cdot 5$ \\
\hline 3. & Functional and technical conditions of storage & $7 \cdot 5$ \\
\hline 4. & $\begin{array}{l}\text { Functional and technical conditions of cold } \\
\text { storage }\end{array}$ & $10 \cdot 0$ \\
\hline 5. & $\begin{array}{l}\text { Functional and technical conditions of kitchen } \\
\text { (preparation, cooking zone, clean or soiled } \\
\text { kitchen pantry) }\end{array}$ & $12 \cdot 0$ \\
\hline 6. & Terms of manipulation & $12 \cdot 0$ \\
\hline 7. & Terms of cooked items & $7 \cdot 5$ \\
\hline 8. & General terms of hygiene and preservation & $10 \cdot 0$ \\
\hline 9. & Terms of food handlers & $10 \cdot 0$ \\
\hline 10. & Residues control & $7 \cdot 5$ \\
\hline 11. & Pest control and hygiene & $5 \cdot 0$ \\
\hline 12. & Food handlers' self-control & $5 \cdot 0$ \\
\hline
\end{tabular}

nine evaluation domains, each including several parameters and accounting ninety-two items (Table 6).

For each domain a specific weight, in percentage, was defined considering its impact on food safety, allowing a quantitative assessment form, according to the same classification grid used by the Northern Public Regional Health Centre, a Portuguese governmental organization.
Table 6 Description of the nine domains for sanitary evaluation of distribution units and their respective values

\begin{tabular}{llr}
\hline Domain & Value (\%) \\
\hline 1. & $\begin{array}{l}\text { Functional and technical conditions of rest } \\
\text { rooms for workers and costumers }\end{array}$ & $6 \cdot 0$ \\
2. & $\begin{array}{l}\text { Functional and technical conditions of clean } \\
\text { pantry and plating }\end{array}$ & $12 \cdot 0$ \\
& $\quad$ Terms of manipulation & $12 \cdot 0$ \\
3. & Terms of cooked items & $7 \cdot 5$ \\
4. & General terms of hygiene and preservation & $10 \cdot 0$ \\
5. & Terms of food handlers & $10 \cdot 0$ \\
6. & Residues control & $7 \cdot 5$ \\
7. & Pest control and hygiene & $5 \cdot 0$ \\
8. & Food handlers' self-control & $5 \cdot 0$ \\
9. & & \\
\hline
\end{tabular}

A specific weight (in percentage) was attributed to each domain taking into consideration its contribution to food safety. Therefore the parameters were quantified according to their relative importance, allowing the results to be converted into the qualitative scale, using the classification presented in Table 4.

\section{Food policies in the school context}

In order to promote nutritional education and organization of several activities in the school context, the following aspects should be taken into consideration:

1. To develop informative and education materials for different age groups (books, activities booklets, concourses, games, food technical sheets, interactive computer disks, videos or movies, fliers, posters, etc.), appealing for this theme.

2. To organize leisure activities focusing on strategies or projects (theatres, dancing, songs, poems, contests, etc.).

3. To develop educational materials for teachers and assistants (guided visits, such as to farms, markets, food industry, supermarkets, universities and high schools, food service units, etc.).

4. To create experimental spaces in schools (kitchen, vegetable gardens, canteens, small laboratories, etc.).

5. To design spaces with decoration related to food themes (teaching classes, canteens, leisure spaces, lobby, aisle, hall, furniture, toilet, etc.).

6. To develop and present an activity plan with specific nutritional education sessions.

7. To establish a bound between food availability (bar, buffet, vending machines, canteen, etc.) and the curricular plan. 
To prevent and identify risk behaviours by excessive or deficient intakes, the intervention strategies should promote a regular evaluation of nutritional status using simple measures such as weight, height, BMI and waist circumference, and an FFQ to students, at the same time controlling determinants of food selection and consumption. It is necessary to know the real context of each school to understand the existing projects and to define priorities for intervention. This software includes a checklist to enable this characterization.

\section{Discussion}

Research enhances the need to attend to the nutritional and energy requirements of children and young people in schools, but also to other factors such as pleasure, enjoyment, well-being, social happiness, learning, good health and self-development ${ }^{(29)}$; and for that purpose models for balanced meals involving different actors in the school setting are being developed. This holistic view of food and meals would be beneficial in order to achieve higher quality of school meals.

Some extensive programmes for food provision have existed in the European countries, Canada and the USA for several decades. Higher relevance to this issue was reinforced by several studies which concluded that although the programmes exist, the meals provided are still unbalanced in terms of nutrients ${ }^{(30,31)}$. Another important factor is the evidence that overweight and obesity have been increasing and strategies and measures have to be taken to reverse this trend ${ }^{(31)}$.

Although Portugal still does not have specific programmes in this field, the government has been active to develop strategies for ensuring better and safe school meals to students, which also contribute to prevention of the development of obesity in younger age.

With the aim to provide school meals that meet both food and nutrient standards, the current working group developed a methodology for planning the menus. This tool - the SPARE software - is available online for free use, aiming to contribute to better management and planning of school meals in Portuguese schools. The data obtained by the grid and checking lists can be used to characterize the present reality of food units concerning the sanitary quality of meals, according to social environment and school food policies.

\section{Acknowledgements}

Sources of funding: This research received no specific grant from any funding agency in the public, commercial or not-for-profit sectors. Conflicts of interest: There are no conflicts of interests. Ethics: Ethical approval was not required. Authors' contributions: A.R., definition of nutritional and dietetic criteria, paper writing and revision;
C.A., definition of nutritional and dietetic criteria, paper writing; M.C.S., definition of quality and hygiene/sanitary criteria; C.M., data collecting and paper writing; B.F., data collecting; R.C., software developing.

\section{References}

1. World Health Organization (2007) The Challenge of Obesity in the WHO European Region and Strategies for Response. Copenhagen: WHO Regional Office for Europe.

2. British Medical Association Board of Science (2005) Preventing Childhood Obesity. London: British Medical Association.

3. Padez C, Fernandes T, Mourão J et al. (2004) Prevalence of overweight and obesity in 7-9 years old Portuguese children: trends in body-mass index 1970-2002. Am J Hum Biol 16, 670-678.

4. Pedrosa C, Correia F, Seabra D et al. (2011) Prevalence of overweight and obesity among 7-9-year-old children in Aveiro, Portugal: comparison between IOTF and CDC references. Public Health Nutr 14, 14-19.

5. Cole TJ, Bellizzi MC, Flegal KM et al. (2000) Establishing a standard definition for child overweight and obesity worldwide: international survey. BMJ 320, 1240-1243.

6. Kuczmarski RJ, Ogden CL, Grummer-Strawn LM et al. (2000) CDC growth charts: United States. Adv Data 314, 1-28.

7. Direcção-Geral da Saúde (2010) Determina a criação das unidades orgânicas flexíveis e estrutura matricial, subdirecções e respectivas competências. Despacho n. ${ }^{\circ}$ 7238/ 2010. Diário da República I Série-B n. ${ }^{\circ} 80$ (2010-04-26): 21905-07.

8. Faculdade de Ciências de Nutrição e Alimentação da Universidade do Porto, em parceria com a Direcção-Geral de Inovação e Desenvolvimento Curricular do Ministério da Educação [para a Plataforma Contra a Obesidade da Direcção-Geral de Saúde] (2009) Sistema de Planeamento e Avaliação de Refeições Escolares (SPARE) [software]. http://www.plataformacontraaobesidade.dgs.pt:8080/SPARE/ apresentacao.php

9. Gabinete de Estatística e Planeamento da Educação (2010) Educação em Números - Portugal 2010. http://www.gepe. min-edu.pt/np4/?newsId=520\&fileName=GEPE_Setembro.pdf (accessed March 2012).

10. Scottish Executive and Food Standards Agency Scotland (2002) Catering for Health: A Guide for Teaching Healthier Catering Practices. Aberdeen: Food Standards Agency Scotland; available at http://www.food.gov.uk/multimedia/ pdfs/cateringforhealthscot.pdf

11. Institute of Medicine (2009) School Meals: Building Blocks for Healthy Children. Washington, DC: The National Academy Press.

12. Marlow HJ, Hayes WK, Soret S et al. (2009) Diet and the environment: does what you eat matter? Am J Clin Nutr 89, issue 5, 1699S-1703S.

13. Sancho T, Candeias A, Mendes C et al. (2008) Promoção da qualidade nutricional das refeições em estabelecimentos de educação do Algarve - análise comparativa 2004/2005 2006/2007. Nutrícias 8, 16-19.

14. Ministério da Educação (2009) Estabelece o regime jurídico aplicável à atribuição e ao funcionamento dos apoios no âmbito da acção social escolar. Despacho n. ${ }^{\circ}$ 55/2009. Diário da República $1^{a}$ Série n. ${ }^{\circ} 2$ (2009-03-02): 1424-33.

15. Lobato LP \& Santos MCTRDT (2010) Grelhas de avaliação higio-sanitária de refeitórios escolares. Aliment Hum 16, 23-28.

16. Instituto Nacional de Saúde Dr Ricardo Jorge (2006) Tabela da Composição de Alimentos. Lisboa: INSA, Centro de Segurança Alimentar e Nutrição. 
17. Núcleo de Estudos e Pesquisas em Alimentação da Universidade Estadual de Campinas (2006) Tabela Brasileira de Composição de Alimentos, $2^{\mathrm{a}}$ ed. São Paulo: NEPA/ UNICAMP.

18. Minister of Health, Health Protection Branch in cooperation with Heath Promotion and Programs Branch (1989) Nutrient Value of Some Common Foods. Ottawa: Canadian Government Publishing.

19. Holland B \& Welch AA (1991) McCance and Widdowson's The Composition of Foods, 5th ed. Cambridge/London: Royal Society of Chemistry/Ministry of Agriculture Fisheries and Food.

20. Eshel G \& Martin PA (2009) Geophysics and nutritional science: toward a novel, unified paradigm. Am J Clin Nutr 89, issue 5, 1710S-1716S.

21. Rodrigues SSP, Franchini B, Graça P et al. (2006) A new food guide for the Portuguese population: development and technical considerations. J Nutr Educ Behav 38, 189-195.

22. Fourth Joint Task Force of the European Society of Cardiovascular and other Societies on Cardiovascular Disease Prevention in Clinical Practice (2007) European guidelines on cardiovascular disease prevention in clinical practice: executive summary. Eur Heart J 28, 2375-2414.

23. Van Horn L, McCoin M, Kris-Etherton PM et al. (2008) The evidence for dietary prevention and treatment of cardiovascular disease. J Am Diet Assoc 108, 287-331.

24. Lichtenstein AH, Appel LJ, Brands M et al. (2006) AHA diet and lifestyle recommendations revision 2006: a statement for healthcare professionals from the Nutrition Committee of the American Heart Association. Circulation 114, 82-96.

25. Meister K (2002) The Role of Eggs in the Diet: Update. New York: American Council on Science and Health.

26. US Department of Agriculture, Center for Nutrition Policy and Promotion (2005) My Pyramid Food Intake Pattern Calorie Levels. My Pyramid assigns individuals to a calorie level based on their sex, age, and activity level. http://www.mypyramid. gov/downloads/MyPyramid_Calorie_Levels.pdf (accessed March 2012)

27. US Department of Health and Human Services \& US Department of Agriculture (2005) Dietary Guidelines for Americans, 6th ed. Washington, DC: US Government Printing Office.

28. World Health Organization (2003) Diet, Nutrition and the Prevention of Chronic Diseases. Report of a Joint WHO/FAO Expert Consultation. WHO Technical Report Series no. 916. Geneva: WHO.

29. Tikkanen I (2011) Nutritionally balanced school meal model for a comprehensive school. $\mathrm{Br}$ Food $J \mathbf{1 1 3}$, 222-233.

30. Burgess AL \& Bunker VW (2002) An investigation of school meals eaten by primary schoolchildren. Br Food $J \mathbf{1 0 4}$, $705-712$

31 Harper C \& Wells L (2007) School Meal Provision in England and Western Countries: A Review. London: School Food Trust; available at http://www.childrensfoodtrust.org.uk/ assets/research-reports/school_meals_review_may07.pdf 